\author{
Maria Jodłowiec ำ https://orcid.org/0000-0002-9651-8810 \\ Jagiellonian University
}

\title{
Explicit Import Revisited: A Critical Appraisal of Explicatures
}

\begin{abstract}
The main goal of this paper is to argue that the way explicitly communicated content is approached in leading pragmatic theories is flawed, since it is posited that explicature generation involves pragmatic enrichment of the decoded logical form of the utterance to full propositionality. This kind of enhancement postulated to underlie explicature generation appears to be theoretically inadequate and not to correspond to the psychological reality of utterance interpretation. Drawing on earlier critique of extant pragmatic positions on explicatures, mainly by Borg (2016) and Jary (2016), I add further arguments against modelling explicitly communicated import in the way leading verbal communication frameworks do. It is emphasized that the cognitively plausible theory of communicated meaning is compromised at the cost of theory-internal concerns.
\end{abstract}

\section{Keywords}

explicature, impliciture, utterance interpretation, pragmatic enrichment, explicit-implicit distinction, contextual cognitive fix

\begin{abstract}
Abstrakt
Głównym celem niniejszego artykułu jest przedstawienie argumentów za tym, że modelowanie treści przekazywanych wprost w komunikacji werbalnej w najważniejszych teoriach pragmatycznych jest obarczone wadami. Przyjmuje się w nich, że odbiór treści komunikowanych eksplicytnie polega na pragmatycznym wzbogaceniu odkodowanej formy logicznej wypowiedzi do uzyskania pełnej formy propozycjonalnej, o określonych warunkach prawdziwości. Ten rodzaj wzmocnienia, związany z dodawaniem materiału pojęciowego do niedookreślonej formy logicznej zdania, nie odzwierciedla adekwatnie praktyki komunikacyjnej i prowadzi do wielu komplikacji na poziomie teorii. Czerpiąc z wcześniejszej krytyki pojęcia eksplikatury, ukazanej w pracach Borg (2016)
\end{abstract}


i Jary'ego (2016), artykuł przedstawia dodatkowe argumenty przeciwko modelowaniu treści przekazywanych wprost w sposób, w jaki robią to czołowe koncepcje pragmatyczne. Podkreśla się, że wiarygodna poznawczo teoria komunikacji werbalnej powinna właściwie oddawać naturę procesów przekazywania i odbioru znaczeń, a proponowane instrumentarium teoretyczne nie może ich zniekształcać.

\section{Słowa kluczowe}

eksplikatura, implikatura, rozumienie wypowiedzi, wzbogacenie pragmatyczne, warstwa eksplicytna i implicytna wypowiedzi, mechanizm kontekstowego zogniskowania poznawczego

\section{Introduction}

The notion of explicature (or impliciture, as explained below) is the cornerstone of dominant pragmatic theories. However, the way explicatures are defined and modelled is highly contentious. The main goal of this paper is to show how the process of explicature generation as conceived in leading pragmatic frameworks is flawed and to explore the nature of the inadequacies involved.

The structure of the paper is as follows. The concept of explicature as developed within the leading pragmatic models is characterised first (section 2), with the emphasis on pragmatic enrichment identified as causing major problems for explicature generation (section 3). The criticism against explicatures as voiced by Borg (2016) and Jary (2016) is summarized in section 4. In section 5, some further critical remarks are added, and a solution of how to deal with the problematic issues is offered. The conclusion sums up the main points made.

\section{Explicitly communicated meaning: Grice (1967/89), Sperber and Wilson (1986/95), Bach (1994), Recanati (2004)}

It is largely agreed by pragmaticists of various persuasions that the meaning conveyed and recovered in verbal exchanges involves two distinct layers, that is explicit and implicit content, with the issue of where and on what grounds the borderline between these two should be drawn remaining controversial and debatable (Carston 2004b; Chaves 2010). It is the explicit side of verbal communication that is in focus here.

Strangely enough, while it might appear that scrutinizing what is explicitly conveyed, as more direct and specific, would be less problematic and more straightforward than dealing with implicit import, surveying the scene 
of pragmatic debates indicates that it is the other way round. There is a lot of controversy and dispute over what is delivered principally as explicit content and there seems to be much less violent disagreement over implicatures, which of course does not mean that everything concerning the implicit layer of communication has been adequately described and explained, and there are a number of accounts competing for primacy in this area. ${ }^{1}$ The roots of the problem with explicit meaning go back to Grice (1967/89), for whom the division of utterance meaning into what is said and what is implicated was instrumental for his working out schema for implicatures. Since Grice's major goal was to explain how implicatures arose, his concern with the explicit layer of communication was only tangential to this objective, hence not explored at depth, causing a lot of debate over how the notion of what is said should be understood. In effect, disputes over how Grice approached explicit meaning continue (see e.g., Baptista 2011; Saul 2002; Terkourafi 2009; Wharton 2002).

However much disagreement there has been over what exactly Grice meant by what is said, most commentators emphasize that his construal of explicit meaning is minimally contextual, since it embraces a decoded input completed only by disambiguation and reference assignment, with all the aspects of the speaker's meaning recovered inferentially through the workings of the conversational maxims treated as implicitly conveyed (Ariel 2002; Bach 1994, 2001; Bezuidenhout and Cutting 2002; Carston 2002b, 2004a, 2007; Carston and Hall 2012; Clark 1996; Hamblin and Gibbs 2003; Ifantidou 2001; Iten 2005; Levinson 2000; Petrus 2010; Sperber and Wilson 1986/95, 2005; Wilson and Sperber 2012). This kind of model allows for a clear-cut division between explicit and implicit utterance meaning, with what is said by definition reduced to what is encoded, supplemented, when required, by disambiguation and reference assignment to be determined contextually. What is implicated is assumed to be derived inferentially on the basis of the maxims of conversation (Carston 2002a: 22).

However elegant, neat and attractive it might appear, this approach is fraught with problems. If, as Grice insists, what is said should necessarily fall within what the speaker actually means (or as the author puts it, "M-intends," where "M" stands for meaning, Grice 1968/89: 123), defining saying in this manner creates problems in a number of cases in which what is communicated departs considerably from what is said in the Gricean sense. In particular, non-literal uses of language, in which speakers commonly do not mean what they actually say, are difficult to reconcile with this

\footnotetext{
${ }^{1}$ For a comprehensive survey on implicature research, see Zufferey et al. (2019), and for a discussion of most recent controversies in implicit import analyses, see Dynel and Cap (2017), Lassiter (2021) and Sbisa (2021).
} 
kind of approach. To overcome this difficulty, Grice suggests that in the case of irony, metaphor, hyperbole and other figurative uses of language "nothing may be said, though there is something which the speaker makes as if to say" (1978/89: 41), the idea being that relying on the Cooperative Principle and the conversational maxims, the addressee is led to recover the intended content (cf. Wilson and Sperber's 2002 criticism of this stance).

Apart from the fact that this kind of solution spoils the neatness of the model, introducing another category in the meaning conveyed by the speaker, who - as is stipulated - may not just say but also "make as if to say" something, it appears problematic in many ways. The Gricean defining criterion of explicit content, based on the (alleged) non-inferential nature of the processing involved, has proved difficult to maintain. As Katz (1972: 449, in Carston 2004a: 829) points out, the resolution of reference, purported to be settled contextually, involves the reliance on Grice's conversational maxims, so it is inevitably inferential, which means that "[s]ince identification of the referent (...) can depend on maxims (...), determining what is said depends on the principles for working out what is implicated." In a similar vein, Walker (1975) and Stalnaker (1989, both in Carston 2002a) have shown that disambiguation rests on inference, putting the final nail in the coffin of the non-inferential treatment of what is said, at the same time destroying what was supposed to be a clear-cut division between the explicit and implicit import of utterances.

Rejecting the idea that what speakers communicate explicitly is generated non-inferentially, Sperber and Wilson (1986/95) posit that the logical form, automatically returned by the language parser, being an incomplete (i.e. non-truth-evaluable) conceptual representation, is inferentially adjusted, completed and enriched by the hearer to full propositional forms, which they call explicatures. Endorsing the underdeterminacy thesis, which states that the semantic content of a given utterance severely underdetermines the intended meaning (see, e.g., Bach 1994, 2007; Jucker et al. 2003; Nerlich and Clarke 2001; Recanati 2002a, 2002b, 2004; Searle 1983; Seuren 2009; Sperber and Wilson 1986/95, 2002, 2008; Wilson and Sperber 2004; Žegarac 2006), relevance theorists view explicature generation as a process of working out the speaker-intended meaning which involves both mandatory and free pragmatic processes (Carston 2002a, 2009, 2010; Carston and Hall 2012; Fretheim 2006; Ifantidou 2001; Sperber and Wilson 1986/95, 2008; Wharton 2009; Wilson and Sperber 2002, 2004, 2012). The former are taken to be triggered by the linguistic forms in the utterance: they include saturation of contextual variables, resolution of ambiguities, reconstruction of the ellipted material, etc., and they are (relatively) uncontroversial, since they are linguistically licensed. The latter, i.e. free pragmatic processes are not sanctioned in this 
way, but they are assumed to be necessary to get a truth-evaluable proposition from the decoded logical form. Since inferences are allowed to play a vital role in calculating explicatures, some researchers (e.g., Bach 2001, 2004; Capone 2006, 2011; Horn 2004, 2010; Levinson 2000) refer to what is involved as "pragmatic intrusion" into the truth-conditional content.

Free pragmatic processes posited in relevance theory as essential in computing explicatures come in two forms, namely as meaning modulation and free enrichment (Sperber and Wilson 1986/95, 2008; Wilson and Sperber 2002, 2004, 2012). Meaning modulation has to do with fine-tuning the meanings of elements present in the logical form. For instance, in an utterance like (1) below, apart from resolving the indexical she, it is vital to adequately adjust the meaning of lovely to get the intended interpretation: in this example, taken from the novel The Da Vinci Code, ${ }^{2}$ the intended referent of she is the Eiffel Tower, and the sense of lovely needs to accord with it.

(1) She is lovely.

While meaning modulation as a process underlying explicatures provokes little controversy, free enrichment is contentious, and, as will be argued below, creates more problems than it solves. Free enrichment is "the incorporation of conceptual material that is wholly pragmatically inferred, on the basis of considerations of rational communicative behavior" (Carston 2004a: 819). Here is Carston's example that illustrates how free enrichment works, with (2a) provided as the explicature of Y's utterance, and ( $2 \mathrm{~b})$ being its implicature:

(2) X: How is Mary feeling after her first year at university?

Y: She didn't pass enough units and can't continue.

(2) (a) MARY $_{X}$ DID NOT PASS ENOUGH UNIVERSITY COURSE UNITS TO QUALIFY FOR ADMISSION TO SECOND-YEAR STUDY AND, AS A RESULT, MARY ${ }_{\mathrm{X}}$ CANNOT CONTINUE WITH UNIVERSITY STUDY. ${ }^{3}$

(b) Mary is not feeling happy

(Carston 2004b: 635)

There is a substantial amount of conceptual material, highlighted in bold in (2a), added in the process of free enrichment of what $\mathrm{Y}$ is supposed to communicate explicitly. In fact, it is not just the number of enhancements introduced that is worrying: there is a whole array of possible additions like, for instance, those in (3a)-(3d), each producing a proposition with different

\footnotetext{
${ }^{2}$ The Da Vinci Code by Dan Brown, Corgi Books, 2004, p. 33.

${ }^{3}$ It is a convention in relevance theory to spell out the content of explicatures in capitals.
} 
truth-conditions, with no principled means of favouring one of the enriched versions over the others. ${ }^{4}$

(3) (a) MARY ${ }_{X}$ DID NOT PASS ENOUGH COURSE UNITS REQUIRED BY THE UNIVERSITY TO BE ABLE TO ENTER SECOND-YEAR STUDY AND, AS A RESULT, MARY ${ }_{X}$ CANNOT CONTINUE WITH THE STUDIES THAT MARY ${ }_{X}$ HAS UNDERTAKEN. ${ }^{5}$

(b) MARY $X$ DID NOT PASS ENOUGH UNIVERSITY COURSE UNITS REQUIRED OF YEAR ONE STUDENTS AND, AS A RESULT, MARY ${ }_{\mathrm{X}}$ CANNOT CONTINUE WITH STUDYING CHEMISTRY.

(c) MARY $_{X}$ DID NOT PASS ENOUGH UNIVERSITY COURSE UNITS THAT WERE OBLIGATORY FOR YEAR ONE STUDENTS AND, AS A RESULT, MARY ${ }_{X}$ CANNOT CONTINUE STUDYING CHEMISTRY.

(d) MARY $_{X}$ DID NOT PASS ENOUGH COMPULSORY COURSE UNITS AT YEAR ONE AND, AS A RESULT, MARY ${ }_{X}$ CANNOT CONTINUE WITH MARY $_{\mathrm{X}}$ 'S TERTIARY EDUCATION.

The term explicature, by analogy with implicature, was originally used by Sperber and Wilson (1986/95), and it has caught on and is applied to refer to explicitly conveyed content as conceived of in other pragmatic frameworks, with the exception of Bach's model. Bach (1994) has introduced the label impliciture to refer to the same kind of content as is covered by explicature, his major reason for calling it in this way being that what the speaker communicates is in fact implicit in what is being said, so as the author emphasizes, remains inexplicit (Bach 2007, 2012).

Content-wise Bach's impliciture is not different from the relevance-theoretic explicature, with two processes that the researcher posits to be responsible for getting the explicitly communicated import, namely completion and expansion. In order to show how completion and expansion work, let us consider examples (4) and (5):

(4) Steel isn't strong enough. (Bach 1994: 127)

(5) I have nothing to wear. (Bach 1994: 136)

Utterances like (4) are treated by Bach (1994) as incomplete proposition radicals: there is a missing conceptual element that is needed for a full proposition to surface, so a completion of what steel is not strong enough for must be supplied to get the propositional speaker-intended meaning (for instance,

\footnotetext{
${ }^{4}$ This example is critically discussed in more detail in Jodłowiec (2015).

${ }^{5}$ Conjunction and (as well as many other conjunctions, discourse markers and function words in general) has been the subject of extensive analyses in neo-Gricean and post-Gricean literature, which will not be reported here as they go well beyond the scope of this paper. For this reason, I do not dispute the meaning of and in any way and stick to Carston's (2004b) idea in this respect.
} 
it may be contextually obvious that steel will not be strong enough to support the planned bridge). It is completion involving contextually available assumptions that is assumed to be required to turn a semantically underdeterminate sentence used by the speaker into a full-fledged proposition.

The situation is viewed differently in the case of (5), which is taken to be a truth-evaluable proposition as it stands but not one that is actually being communicated by the speaker. It is manifestly false that the speaker literally has nothing to wear and in order to arrive at what is really meant, expansion, which involves conceptual strengthening (Bach 1994: 134), is necessary. So in a certain context it may be apparent that by uttering (5) the speaker means that she has nothing appropriate to wear to the wedding she is about to attend. ${ }^{6}$

The major difference between completion and expansion is that while the former is called for to turn proposition radicals into full propositions, so it is conceptually required, the latter results in fine-tuning of a minimal proposition as expressed by the utterance, hence is just pragmatically mandated (Bach 1994, 2012). ${ }^{7}$ Both entail adding extra components into the decoded form, so they are par excellence enrichments.

While relevance-theoretic explicatures and Bach's $(1994,2012)$ implicitures are inferential (with the former framed by the workings of the Communicative Principle of Relevance, the presumption of optimal relevance and relevance comprehension heuristic, and the latter based on Gricean conversational maxims), in Recanati's (2004) model the processes responsible for generating what is said, or the so-called primary meaning, are assumed to be associative in nature (see Carston 2007). This means that on Recanati's (2004: 28-29) approach the explicit import is taken to be contextually settled and based on saliency, where the "dynamics of accessibility does everything, and no 'inference' is required" (2004: 32). ${ }^{8}$ Even though the framework under discussion embraces meaning-finetuning and free enrichment at the level of explicit meaning, Recanati provides virtually no explanation how non-linguistically mandated constituents get incorporated into the primary propositional content. It is assumed that in all cases where specification of meaning is required to arrive at the speaker meaning, as is the case in (6) below, enrichment will come into play, yielding (6a) but the details of how it is achieved are not specified.

\footnotetext{
${ }^{6}$ Conforming to the convention followed by many pragmaticists, I will refer to the speaker as she and to the hearer as he.

${ }^{7}$ For some objections that this kind of analysis raises, see Soames (2010: Ch. 7).

${ }^{8}$ For an in-depth analysis of problems with this kind of construal, see Carston (2007).
} 
(6) The table is covered with books. (Recanati 2004: 8; originally used by Strawson 1950: 328)

(6) (a) THE TABLE IN THE LIVING ROOM IS COVERED WITH BOOKS.

The resulting explicature appears to be not much different from what relevance theory would recognize as such, and as Recanati (2007) himself admits, there is a lot of similarity in the two pragmatic theories as far as explicit import is concerned. His primary utterance meaning is in many respects like relevance-theoretic explicatures, though due to associative rather than properly inferential nature of the underlying processes, it is also qualitatively different.

On each of the construals of explicature described above, developed within three different pragmatic theories, the computation of explicit import is postulated to involve enrichment, that is the incorporation of unarticulated constituents - to be understood as "constituents of the interpretation corresponding to no constituent in the sentence being interpreted" (Recanati 2010: 22) - into the representation of the explicitly communicated meaning. This is a contentious solution.

\section{Against enrichment}

A number of semanticists (i.a., Corazza and Dokic 2007, 2012; Martí 2006; Stanley 2000; Stanley and Szabó 2000; Taylor 2001) reject the idea of adding constituents not represented in the linguistic structure of the sentence in order to arrive at the explicit import conveyed. It is contested as unmotivated and not adequately constrained.

As Stanley $(2000,2005)$ points out, endorsing free enrichment as an explicature generation procedure causes the overgeneration problem. His argument is built around examples like those in (7) and (8).

(7) Everyone likes Sally.

(7) (a) EVERYONE LIKES SALLY AND HIS MOTHER.

(8) Every Frenchman is seated.

(8) (a) EVERY FRENCHMAN IN THE CLASSROOM IS SEATED.

(b) EVERY FRENCHMAN OR DUTCHMAN IS SEATED.

Stanley's (2000) point about (7) is that if it is uttered in a party context in which everybody invited is known to like and appreciate their mother in answer to a suggestion about inviting another guest, Sally, it will not (and cannot) be understood as communicating (7a), even though the existence of 
a tacit pragmatic strategy responsible for enriching what has been expressed by the speaker allows for this kind of development of the content. The challenge in (8), as Stanley (2005) observes, is to explain why it can be readily enriched to express (8a) but not (8b). His question is: how to block the generation of unreasonable (8b) in a model with free enrichment, which could easily derive (8a) from (8) on purely pragmatic grounds? This leads Stanley (2000, 2005) and some other critics of free enrichment (e.g., King and Stanley 2005; Martí 2006; Stanley and Szabó 2000) to come up with a counterproposal. It is suggested that all context-sensitive meaning adjustments should be linguistically mandated by the presence of the so-called hidden indexicals in the underlying logical form of the utterance. These covert variables are postulated to give rise to occasion-specific concepts at the level of utterance meaning, which means that ultimately enrichment is replaced by saturation (for a more detailed discussion, see Jodłowiec 2015).

This kind of overgeneration argument is refuted by relevance theorists. Carston (2002c, 2004a, 2009), Hall (2008a, 2008b, 2009), and Carston and Hall (2012) rebut the charges mounted against free enrichment by the proponents of hidden-indexicals by showing that the purported overgeneration problem ensues from a major misconception about free enrichment. As is expounded by the scholars, on the one hand, only enrichments that produce manifestly speaker-intended and contextually relevant cognitive effects can be generated in the course of recovering explicatures, which - in normal circumstances - rules out the derivation of (7a) from (7), and (8b) from (8). On the other hand, all permissible enrichments must be necessarily local, that is, only those that operate on constituents of propositions (and not on whole propositions) are permitted. A crucial factor then, overlooked in the overgeneration polemic, has to do with the important constraint on enrichment: in principle, only enrichments that warrant the implicature that is evidently intended by the speaker will go through (Hall 2008a, 2008b). ${ }^{9}$

Some other opponents of free enrichment, Corazza and Dokic (2007, 2012), eliminate the procedure altogether, advancing a model of situated minimalism or situationalism, as they call it. Instead of freely enriched explicatures, Corazza and Dokic $(2007,2012)$ postulate situational anchoring for propositions expressed by utterances, ensuring the derivation of context-sensitive meanings. On this approach, the specific truth-value (and, as a result, the meaning) of, for instance, (9) is simply (9a). Depending on the situation relative to which (9) is evaluated, the proposition expressed can either be that there is beer suitable for drinking in the fridge (for instance, if the speaker is making a suggestion about how the hearer could quench his thirst), or in a different situation (for example, in a fridge cleaning scenario),

\footnotetext{
${ }^{9}$ See Hall (2008a, 2008b: Ch. 3) for the criticism of the hidden indexical programme.
} 
that there are still some beer stains in the fridge that need to be cleaned (Corazza and Dokic 2012: 186).

(9) There is some beer in the fridge.

(9) (a) An utterance of $u$ of "There is some beer in the fridge" is true iff there is some beer in the fridge in the situation of $u$. (Corazza and Dokic 2012: 187)

As Corazza and Dokic $(2007,2012)$ point out, unlike free enrichment, which allows the identification of the meaning directly conveyed by the speaker through adding conceptual material to the decoded logical form, situationalism posits that truth-values of utterances are sensitive to implicit situations, relative to which they are evaluated. These situations need not be conceptually identified by subjects, who are simply in them (Corazza and Dokic 2007: 180). The relevant standards of interpretation are thus assumed to be part of the situations in which interactants happen to be functioning rather than to reside in the discussants' minds (Corazza and Dokic 2007: 175). On this approach, there is no "cognitive burden" on the comprehender that Corazza and Dokic (2007: 176) see in free enrichment, which I consider to be a substantial asset of the proposal. However, it is left unexplained how the adjustment to context-sensitive meanings is supposed to be achieved, granted that the situations may not be conceptualized by interactants. Since the scholars' commitments are mainly philosophical, it can only be expected that psychological plausibility of the framework will not be high on their agenda, so it is not one of their concerns.

Nevertheless Corazza and Dokic (2007: 175) do spotlight an acute problem that requires adequate attention from pragmaticists interested in developing rational models of utterance production and comprehension. Any specification of meaning embracing enrichment, which results in appending extra conceptual material to the decoded form, increases the cognitive expenditure of the comprehension process. This is tantamount to incorporating into the utterance interpretation model a cognitively inefficient procedure, which undermines its economy of functioning. This, I believe, is a major problem with enrichment, which has not been adequately attended to by pragmaticists.

What is probably even more worrying than the unmet economy parameter is the reflection that no enrichment can ever be satisfactory. As was aptly argued by Wettstein (1979) long ago, any attempt to make underdetermined aspects of an utterance fully explicit is bound to fail. As the author underscores, there will always be competing and non-synonymous ways to express the specific meaning, and even the speaker, if asked to choose the one that best corresponds to the meaning that is aimed at, may not be ready to decide. "The speaker will often be aware of several descriptions, each of 
which uniquely picks out his referent, and will not be able to select one of these descriptions as the correct one, the one that captures what he meant by his utterance of 'it'. Accordingly, if asked which eternal sentence formulates the proposition he meant to assert, he will not be able to answer" (Wettstein 1979: 94, original emphasis). Eternal sentences, that is those encoding a complete proposition including all context-sensitive additions, simply do not exist in natural language (Carston 2002a).

As hinted at above, there are usually different ways to enrich the logical form of an utterance. ${ }^{10}$ Examples (3a)-(3d) demonstrate that several developments of the decoded sentence at the explicit level are possible and there is no principled means of choosing the intended one. Since they are not truthconditionally equivalent, the different versions constitute different propositions, and in consequence, different explicatures. That is a fatal blow to theories of verbal communication which rely on enrichment as an explicature-generating pragmatic process. It should be stressed then, that overgeneration, but of the type just described and not the kind allegedly detected by the endorsers of hidden indexicals, is indeed a problem for free enrichment.

\section{Against explicatures}

While there are serious concerns over how to account for explicit utterance content that comprehenders are supposed to recover, as evidenced by the discussion above, there are also problems with the notion of explicature per se. Severe criticism against the way explicatures are defined is voiced by Borg (2016). As the author argues, the content identified to belong to explicature by what she labels the canonical, psychological and communicative definitions widely diverges, so her conclusion is that "[e]xplicatures, then, as things which are supposed to simultaneously satisfy all the three roles, simply explode" (Borg 2016: 336).

Taking on board the canonical definition, in accordance with which explicature is a development of the logical form into full propositionality, Borg (2016) questions not only free pragmatic processes that are supposed to underlie explicature generation but also the explicit-implicit distinction compatible with the canonical construal. The problem is that it becomes completely blurred if free pragmatic effects are postulated to be involved in computing explicit as well as implicit content communicated by the utterance. Discussing this issue, the researcher brings in a very interesting example, cited in

${ }^{10}$ This is well-documented in the case of utterances involving quantifier domain restriction (for a useful discussion of problems with quantifier domain restriction, see Buchanan 2010; for a comprehensive discussion of the enrichment fallacy, see Jodłowiec 2015). 
(10) below. The point is that B's answer in (10) is compatible with explicature in (10a) and (10b) but it is only the former that warrants the implicature that $\mathrm{B}$ refuses to have dinner with $\mathrm{A}$, as (10b) directly, in other words explicitly, communicates the non-acceptance of the dinner offer, which appears totally counterintuitive.

(10) A: Do you want to have dinner?

B: I'm going to the cinema.

(a) I'M GOING TO THE CINEMA TONIGHT

(b) I'M GOING TO THE CINEMA AT A TIME THAT MAKES HAVING DINNER WITH A IMPOSSIBLE (Borg 2016: 344)

The alarming detail here is that there is no operational constraint that would bar the development of B's utterance into explicature (10b). I think this example epitomizes the problems that free enrichment creates and reveals that they cause grave concern for pragmatic theories founded on the concept of explicature, as presented in section 2 above.

Examining psychological definitions of explicatures, that is those which focus on the thinking processes of speakers and hearers accompanying communication and the interactants' commitments at play, Borg (2016) lists five different functions that they are recognized to perform. As the researcher (2016: 346) contends, "it is not at all obvious that there is a unique content which fulfils all these functional roles nor that any content which does play a given functional role necessarily lines up with the canonical definition of explicature content in the way the Pragmaticist envisages." I am afraid that some of the enumerated functions may not accurately reflect what is assumed to be involved, since, for example, nowhere is it claimed in relevance theory that explicatures embrace "the first content hearers recover via relevance processing” (function (ii), Borg 2016: 346), nevertheless the principal critical point that is advanced does hold. The important point that Borg (2016) makes at this juncture is that the communicative behaviour of speakers and hearers does not have to depend on their entertaining full-fledged propositions. Speakers' thoughts that give rise to utterances are often underdetermined, and hearers may not need to work out propositionally complete explicatures to grasp the intended meaning, for instance, if the major communicative import of the utterance is conveyed by the implicature. I will return to this issue and build on this idea below (see section 5).

Referring to communication-based definitions, Borg (2016) explores the normative dimension of explicatures, arguing that what is explicitly communicated framed as it is in the leading pragmatic theories, neither warrants the adequate identification of content for truth-value judgements nor 
allows for establishing clear conditions under which speakers might be held responsible for what they have asserted. Borg's overall conclusion is that explicature is an ill-defined notion, "explanatorily otiose" (Borg 2016: 352) and by and large detrimental to pragmatic theories.

While Borg's (2016) objections to the way explicatures are defined and her observations on how their different functions diverge and, as a result, create an incoherent picture of their role and character are certainly valid, there is some overlap in the categorial definitions that are distinguished and, in consequence, some repetition (and redundancy) in the criticism she directs at explicatures. In particular the functions of psychological and communication-based explicatures in Borg's classification appear to cross-cut, and in effect, the speaker's liability is appealed to in both categories. Thus critical arguments of similar nature related to the speaker's commitments are advanced with reference to what is claimed (not fully accurately in my estimation) to apply two different explicature construals. It is not my aim though to engage in polemic with Borg (2016) about a few minor particulars. I think her criticism of the way explicature is conceptualized is on the whole judicious and revealing.

A slightly different critical perspective on explicatures, though equally damaging to the concept as such, is taken by Jary (2016). His analysis of what the interpretation process of assertoric utterances consists in leads the author to conclude that explicatures serve no well-motivated purpose in pragmatic processing, which undermines the role they have been assigned in verbal communication models. Jary's (2016) major argument is that the identification of explicit content, especially as involving adjusting and augmenting the utterance's content, should not be identified as a constitutive component of comprehension. The point of departure for the re-examination of explicit content for the researcher is the focus on the difference between utterances and their interpretations. It is a basic misconception that persists in most pragmatic models to treat these two as belonging to the same species of phenomena. As Jary (2016: 26) contends, "utterances are events that consist in the production of tokens of linguistic types for communicative purposes, and interpretations are constraints on behaviour, verbal or otherwise, that result from those utterances. In the case of an assertion, the constraints can be thought of as inferential and practical commitments and entitlements undertaken by the speaker, and also by the hearer if he assents to the assertion." It is emphasized that interpretations are not strictly speaking semantic entities and are substantially different from linguistic forms that they derive from. Showing that (i) explicatures in the form of adjusted and enriched content do not necessarily reflect the intuitions people have about what is asserted, (ii) that the scope test advocated by some pragmaticists (e.g., Carston 2002a; Recanati 1989) to differentiate the aspects of utterance 
meaning explicitly communicated from those communicated implicitly should best be seen as the test for materially as opposed to behaviourally implicated content (for details, see Jary 2013) and (iii) that explicatures do not represent a step in utterance interpretation indispensable to modelling verbal comprehension, Jary (2016) convincingly argues against explicatures as adjusted and enhanced representations of the encoded utterance meaning. Remaining sceptical about Jary's distinction between material and behavioural implicatures (for some critical remarks, see Jodłowiec 2015), I agree with the spirit of Jary's criticism and find his ideas on the distinction between utterances and their interpretations quite inspiring.

\section{Explicatures: Important insights and more critique}

Detrimental as they are to the concept of explicature as conceived in existing pragmatic models, the arguments presented above do not exhaust a catalogue of problems with explicatures and in this section I will add some more.

Leaving aside some minor inadequacies in how Borg's argument is being developed hinted at above, it needs to be emphasized that what she exposes in her paper are indeed fundamental flaws in the way the concept of explicature is deployed. Her critical commentary to a certain degree dovetails with the critique of explicatures presented in Jodłowiec (2015). The backbone of the criticism levelled against explicature in this monograph has to do with free pragmatic processes posited to contribute to explicature generation. However, there are some more objections against explicatures which go beyond the critical comments made by Borg (2016) and the remarks that I offered earlier (Jodłowiec 2015, 2019) that I would like to voice here.

In the first place, I want to fully endorse the idea that what hearers recover as conversationally pertinent content may not necessarily involve the retrieval of explicature in the form of a complete proposition. As an expanding body of research into good-enough interpretations demonstrates (e.g., Karimi and Ferreira 2016; Paape, Vasisht and von der Malsburg 2020; Qian, Garnsey and Christianson 2018 and references therein), comprehenders are frequently satisfied with interpretations that fall short of being complete propositional representations as long as the interactants' current communicative goals are satisfied. As experimental evidence indicates, people do not necessarily engage in full syntactic, semantic and/or pragmatic analyses of incoming verbal data, and often end up with incomplete meaning representations.

It must be pointed out that this perfectly accords with the orientation to optimally relevant interpretations as professed within the relevance-theoretic framework. It is assumed on this approach that the chief driving force 
(as well as constraint) in utterance comprehension has to do with attaining a satisfying range of cognitive effects (Sperber and Wilson 2008: 89-90). The hearer is assumed to follow a path of least effort and as soon as he achieves cognitive satisfaction, which means that the effort invested in processing the verbal input returns sufficient gratification in terms of communicative effects (arriving at what is referred to as optimally relevant interpretation), he is entitled to proceed no further (Sperber and Wilson 2005). With reference to explicatures, which are in focus here, this kind of shallow processing may be predicted to be enacted particularly in situations where the locus of meaning conveyed in a given communicative context lies beyond the explicit meaning per se and resides in what is implicated. As long as the manifestly intended implicature can be worked out from a sketchy, non-fully propositional utterance meaning, it will suffice. Let us consider the exchange in (11).

(11) X: Shall we go to the movies?

Y: I must finish Sally's text tonight.

In order to understand that Y's answer to X's suggestion is negative, the addressee does not have to grasp the full meaning of Sally's text, which, in principle, may convey a set of different senses: it can refer to the text Sally has written (and has asked Y to translate), or the text Sally has translated (and has asked Y to proofread) or the text Sally has illustrated (and has asked $\mathrm{Y}$ to edit), to mention just the most obvious explicit interpretations of the phrase. In other words, my claim is that the comprehension of Y's utterance can proceed without the proper precisification of what Sally's text actually stands for. As shown elsewhere (Jodłowiec and Piskorska 2015, 2020), this kind of approach can be used to explain how metonymies work.

It is truly surprising that the relevance-theoretic framework, with the inbuilt principle of cognitive economy in the form of the Communicative Principle of Relevance (Sperber and Wilson 1986/95; Wilson and Sperber 2012), excludes this kind of comprehension move. As Jary (2016: 33, fn 4) indicates following Allot's arguments (presented in his $2007 \mathrm{PhD}$ dissertation, supervised by Deirdre Wilson), in relevance theory implicatures are warranted only by fully inferentially developed explicatures. This means that shallow processing as described here would be barred as incompatible with the theoretical assumptions of the relevance-theoretic model.

There is another vital issue to be addresses in this context. Example (11) is much like the one in (10), cited earlier from Borg (2016). Let me explore in some detail Borg's (2016: 341-342) suggestion that instead of two pragmatic processes posited to contribute to explicatures, viz. unarticulated constituents and meaning modulation, the former - highly controversial in the light of the arguments presented earlier - might be eliminated, since modulation 
itself might do the job. This is precisely the kind of solution that I considered earlier (Jodłowiec 2015), which Borg was unaware of, in order to remove the cognitive burden that enrichment as the explicature-generating device is recognized to cause. My proposal is the comprehension model embracing the procedure labelled contextual cognitive fix that settles underdeterminacies at the level of mental representations. This brings us directly to another germane point that I would like to elaborate on, namely the difference between utterances and their interpretations that has already emerged in the discussion of Jary's arguments above.

What Jary's (2016) deliberations over the status and purpose of explicatures bring to light is the juxtaposition between utterances and their interpretations, which I think is critical to modelling verbal comprehension in a psychologically plausible way but has been overlooked or ignored by pragmaticists. However, whereas for Jary the utterance vs. utterance interpretation distinction delineates the contrast between linguistic forms vs. inferential and practical commitments that the speaker can be made responsible for by virtue of using these linguistic forms, I would like to foreground a different aspect of the contrast between the two. It is essential to observe that while utterances are linguistic entities, their interpretations are mental (commonly assumed to be subpersonal, see Carston 2002a) representations. Therefore it appears a misconception to think of explicature, being the level of verbal interpretation which has to do with the directly conveyed meaning, in terms of the development of the utterance's logical form into a "fully explicit"11 linguistic representation: explicatures are entities that belong to the language of thought, not natural language entities. In other words, explicatures are qualitatively different from utterances that give rise to them, so the move from what the speaker says to what is explicitly conveyed by what she says involves a transfer from the realm of linguistic entities to a realm of conceptual entities. To be sure, we know next to nothing about the language of thought (or mentalese) and the only language that we can use to elucidate utterance interpretation is the language we use in communication. While this in an unavoidable strategy, it must be remembered that utterances and their interpretations are different in kind, in a similar way in which words (as linguistic objects) are different from the mental concepts (that is cognitive objects) they are associated with. Now that this issue has been made clear, contextual cognitive fix can be discussed in some more detail.

Unlike enrichment, which adds conceptual material to the decoded representation, contextual cognitive fix is assumed to operate at the level of the language of thought, performing contextual meaning fine-tuning or what can roughly be viewed as meaning modulation, which corroborates

${ }^{11}$ In inverted commas, because as argued above, full linguistic explicitness is unattainable. 
Borg's (2016) suggestions. The underlying claim is that in the same way in which the speaker's thought which triggers a given utterance is an individuated cognitive representation in her mind, so is the thought that the hearer forms as the result of processing her utterance, both being mentalese representations. In other words, in the construal under discussion it is hypothesized that comprehension results in the hearer fixing on the specific concepts that are activated by linguistic forms used by the speaker. The components of the hearer's thought are assumed to be arrived at inferentially, via the comprehension heuristic in accordance with which the easiest route to obtaining a satisfying range of cognitive effects is followed.

All this means that if communication is successful, the concepts that originate in the speaker's mind will also - as a result of utterance processing - be entertained by the hearer. Furthermore, it is assumed that the constituents of thought are in a causal relationship to the entities, properties, actions, relations, locations, etc. in the world (in fact, real or possible, as the case may be) in that they may be directly caused by them or by processing ostensive verbal stimuli that make reference to them (cf. Carston 2002a: 1.7.1). Thus, to return to one of the examples used earlier, if in commenting on the Eiffel Tower, I utter (1) She is lovely, I will be understood to communicate that the Eiffel Tower is lovely not because the addressee will substitute the Eiffel Tower for she, but thanks to the recipient's capacity to identify the intended entity I am referring to, adjusting also the sense of lovely to appropriately fit in with this object in order to grasp the intended meaning. When processing the utterance in (2), whose relevant part is repeated for the reader's convenience as (12) below, the hearer is not hypothesized to flesh out and enrich what has been decoded to get its specific meaning but fix on the conceptual representation that returns an adequate range of effects, as manifestly intended by the speaker in context (hence the term contextual cognitive fix). The schematic representation of the meaning recovered might be something like (13).

(12) She didn't pass enough units and can't continue.

(13) MARY $_{x}$ DID NOT PASS* ENOUGH UNITS AND* $^{*}$ MARY $_{x}$ CANNOT
CONTINUE $_{\mathrm{m}}{ }^{12}$

What (13) is supposed to depict is that the hearer recovers a representation of the speaker's intended explicit content with occasion-specific meanings

\footnotetext{
${ }^{12}$ It must be underscored that despite their superficial similarity to formulas employed by the proponents of hidden indexicals, the schematic representation used here has nothing to do with this kind of analysis: it just implements a similar notation. Hidden indexicals are assumed to belong to the logical form of utterances, whereas the schematic representations used here are supposed to depict (even if inaccurately, see the footnote that follows) the components of language users' thoughts.
} 
that are contextually fixed (as the indices show).$^{13}$ The meanings of certain components, in particular UNITS and CONTINUE, even though not fully conceptually developed, are read off as unequivocal in the context in which they are applied. The asterisks in the formula indicate that the meanings of the specific concepts that the decoded words provide access to are fine-tuned to their contextually intended senses. On this construal, explicatures are "informationally exact" (to borrow the convenient phrase from Vicente and Martínez-Manrique 2005: 551) language of thought formulas.

This kind of modelling of explicatures eliminates the troublesome enrichment process from explicature generation. It is also worth pointing out that on the contextual cognitive fix construal it is predicted that the less than fully developed representations will be recovered whenever they yield a satisfying range of cognitive effects. It can also be expected that mental representations formed in the course of utterance interpretation will be to a lesser or greater degree idiosyncratic, since the fixation on specific conceptual elements in the representation recovered by hearers may vary to some extent, depending on the structure and content of concepts available to a given comprehender when the utterance is being processed. The recovered explicit content can be more (or less) conceptually satiated, depending on where the shortest relevance-oriented route will take the hearer. The cognitive contextual fix also accounts for communication failure, which can be viewed as erroneous contextual fixation (for a more detailed discussion, see Jodłowiec 2015).

\section{Conclusion}

The notion of explicature incorporated in the prominent pragmatic models is supposed to account for how semantic underdeterminacies are resolved but free pragmatic processes postulated to do the job have proved highly problematic, undermining the status and role of explicature in modelling verbal comprehension. The linguistic adjustment/enhancement approaches have been challenged on the grounds of cognitive inefficiency (since adding conceptual material in representing explicit import increases mental energy expenditure). They ratify potential proliferation of propositional forms without making available an adequate criterion for identifying a single explicature to be identified as contextually intended. Worst of all, they model communicative behaviours of interactants in the way that departs from observations about the production and comprehension of utterances, in effect distorting the reality of verbal communication.

\footnotetext{
${ }^{13}$ The proviso that this is only an inaccurate depiction of what in fact is the language of thought representation is in force.
} 
As argued in this paper, the recovery of explicit meaning takes place at the level of utterance interpretation, so it belongs to the sphere of conceptual (and not strictly linguistic) operations and must be viewed as such. The contextual cognitive fix construal as described here is cognitively frugal and eliminates the proliferation of truth-conditionally different candidates for explicature. It is also compatible with the idea that utterance interpretations may be, and frequently are, sketchy, and the stage of a complete propositional representation of explicitly communicated content is sometimes bypassed if satisfying cognitive effects can be recovered taking a shorter (and more economical) comprehension route.

This observation leads to another important issue related to pragmatic theories. The explicit-implicit distinction that they build upon can be useful for theoretical purposes but it may not reflect adequately the psychological reality underlying verbal communication. Human communication does not depend on the explicit-implicit contrast. So, while it may be a convenient idealization from the theoretical perspective to frame the speaker's meaning as embracing the explicit and implicit layer, it does not reflect accurately the processes underlying utterance comprehension, and as a result, it distorts the account of verbal communication. This means that from the perspective of cognitive processes, the distinction blurs the picture and is superfluous, being "more like shackles than wings for ideas," to borrow a nice metaphor from Jaszczolt (2021: 204).

\section{References}

Allot Nicolas (2007). Pragmatics and Rationality. Unpublished PhD thesis, University College London.

ArIEL Mira (2002). Privileged interactional interpretations. Journal of Pragmatics 34, 1003-1044.

BACH Kent (1994). Semantic slack: What is said and more. In Foundations of Speech Act Theory: Philosophical and Linguistic Perspectives, Savas Tsohatzidis (ed.), 267-291. London: Routledge.

BACH Kent (2001). You don't say. Synthese 128, 15-44.

BACH Kent (2004). Pragmatics and the philosophy of language. In The Handbook of Pragmatics, Laurence Horn, Gregory WARD (eds.), 463-487. Oxford: Blackwell.

BACH Kent (2007). Regression in pragmatics (and semantics). In Pragmatics, Noel Burton-Roberts (ed.), 24-44. Basingstoke: Palgrave Macmillan.

BACH Kent (2012). Saying, meaning, implicating. In The Cambridge Handbook of Pragmatics, Keith Allan, Kasia Jaszczolt (eds.), 47-67. Cambridge: Cambridge University Press.

BAptista Luca (2011). Say what? On Grice on what is said. European Journal of Philosophy 21(1), 1-19. 
Bezuidenhout Anne, Cutting Cooper (2002). Literal mining, minimal propositions and pragmatic processing. Journal of Pragmatics 34, 433-456.

Borg Emma (2016). Exploding explicatures. Mind \& Language 31(3), 335-355.

Buchanan Ray (2010). A puzzle about meaning and communication. Nous 44(2), 340-371.

CAPone Alessandro (2006). On Grice's circle (a theory-internal problem in linguistic theories of the Gricean type). Journal of Pragmatics 38, 645-669.

CAPone Alessandro (2011). Knowing how and pragmatic intrusion. Intercultural Pragmatics 8(4), 55-83.

Carston Robyn (2002a). Thoughts and Utterances. The Pragmatics of Explicit Communication. Malden, MA: Blackwell.

CARston Robyn (2002b). Linguistic meaning, communicated meaning and cognitive pragmatics. Mind \& Language 17(1-2), 127-148.

CARston Robyn (2002c). Metaphor, ad hoc concepts and word meaning - more questions than answers. UCL Working Papers in Linguistics 14, 83-105.

Carston Robyn (2004a) Explicature and semantics. In Semantics: A Reader, Steven DAvis, Brendan Gillon (eds.), 817-845. Oxford: Oxford University Press.

CARston Robyn (2004b). Relevance theory and the saying/implicating distinction. In The Handbook of Pragmatics, Laurence Horn, Gregory WARD (eds.), 633-656. Oxford: Blackwell.

CARston Robyn (2007). How many pragmatic systems are there? In Saying, Meaning, Referring: Essays on the Philosophy of François Récanati, Maria Jose Frapolli (ed.), 18-48. Basingstoke: Palgrave Macmillan.

CARston Robyn (2009). The explicit/implicit distinction in pragmatics and the limits of explicit communication. International Review of Pragmatics 1(1), 35-62.

CARston Robyn (2010). Explicit communication and 'free' pragmatic enrichment. In Explicit Communication: Robyn Carston's Pragmatics, Esther Romero, Belén Soria (eds.), 217-287. Basingstoke: Palgrave Macmillan.

Carston Robyn, Hall Alison (2012). Implicature and explicature. In Cognitive Pragmatics, vol. 4, Hans-Jörg Schmid (ed.), 47-84. Berlin: Walter de Gruyter.

Chaves José (2010). Explicature, what is said, and Gricean factorization criteria. In Explicit Communication: Robyn Carston's Pragmatics, Esther Romero, Belén SorIA (eds.), 109-125. Basingstoke: Palgrave Macmillan.

Clark Herbert (1996). Using Language. Cambridge: Cambridge University Press.

Corazza Eros, Dokic Jérôme (2007). Sense and insensibility or where minimalism meets contextualism. In Context-Sensitivity and Semantic Minimalism: New Essays on Semantics and Pragmatics, Gerhard Preyer, Georg Peter (eds.), 169-193. Oxford: Oxford University Press.

Corazza Eros, Dokic Jérôme (2012). Situated minimalism versus free enrichment. Synthese 184, 179-198.

Dynel Marta, CAP Piotr (2017). Implicitness: Familiar terra incognita in pragmatics. In Implicitness: From Lexis to Discourse, Piotr CAP, Marta Dynel (eds.). Amsterdam: John Benjamins.

Fretheim Thornstein (2006). English then and Norwegian da/sa compared: A relevance-theoretic account. Nordic Journal of Linguistics 29(1), 45-93. 
Grice H. Paul (1967/89). Logic and Conversation. William James Lectures. Reprinted in Studies in the Way of Words, H. Paul Grice (1989), 3-143. Cambridge, MA: Harvard University Press.

GRICE H. Paul (1968/89). Utterer's meaning, sentence meaning and word-meaning. Foundations of Language 4, 225-242. Reprinted in Studies in the Way of Words, H. Paul Grice (1989), 117-137. Cambridge, MA: Harvard University Press.

Grice H. Paul (1978/89). Further notes on logic and conversation. In Syntax and Semantics 9: Pragmatics, Peter Cole (ed.), 113-127. New York: Academic Press. Reprinted in Studies in the Way of Words, H. Paul Grice (1989), 41-57. Cambridge, MA: Harvard University Press.

Hall Alison (2008a). Free enrichment or hidden indexicals? Mind \& Language 23, 426-456.

Hall Alison (2008b). Free Pragmatic Processes and Explicit Utterance Content. Unpublished $\mathrm{PhD}$ thesis. University of London.

Hall Alison (2009). Semantic compositionality and truth-conditional content. Proceedings of the Aristotelian Society 109(3), 353-364.

Hamblin Jennifer L., Gibis Raymond W. (2003). Processing the meanings of what speakers say and implicate. Discourse Processes 35(1), 59-80.

Horn Laurence (2004). Implicature. In The Handbook of Pragmatics, Laurence Horn, Gregory WARD (eds.), 3-28. Oxford: Blackwell.

Horn Laurence (2010). WJ-40: Issues in the investigation of implicature. In Meaning and Analysis. New Essays on Grice, Klaus Petrus (ed.), 310-340. Basingstoke: Palgrave Macmillan.

IfANTIDOu Elly (2001). Evidentials and Relevance. Amsterdam: John Benjamins.

Iten Corinne (2005). Linguistic Meaning, Truth Conditions and Relevance: The Case of Concessives. Basingstoke: Palgrave Macmillan.

JARY Mark (2013). Two types of implicature: material and behavioural. Mind \& Language 28(5), 638-660.

JARY Mark (2016). Rethinking explicit utterance content. Journal of Pragmatics 102, 24-37.

Jaszczolt Katarzyna (2021). Functional proposition: A new concept for representing discourse meaning? Journal of Pragmatics 171, 200-214.

JodŁow IEc Maria (2015). The Challenges of Explicit and Implicit Communication: A Relevance-Theoretic Approach. Frankfurt am Main: Peter Lang.

JodŁowiec Maria (2019). Generating explicatures: Free enrichment vs. contextual cognitive fix. In Text - Sentence - Word. Studies in English Linguistics, vol. 3, Agnieszka Uberman, Magdalena Trindel (eds.), 9-22. Rzeszów: Wydawnictwo Uniwersytetu Rzeszowskiego.

JodŁowiec Maria, Piskorska Agnieszka (2015). Metonymy revisited: Towards a new relevance-theoretic account. Intercultural Pragmatics 12(2),161-187.

JodŁowiec Maria, Piskorska Agnieszka (2020). Metonymic relations - from determinacy to indeterminacy. In Relevance Theory, Figuration, and Continuity in Pragmatics, Agnieszka Piskorska (ed.), 45-65. Amsterdam: John Benjamins.

Jucker Andreas, Smith Sara, Ludge Tanja (2003). Interactive aspects of vagueness in conversation. Journal of Pragmatics 35, 1737-1769.

KARIMi Hossein, Ferreira Fernanda (2016). Good-enough linguistic representations and online cognitive equilibrium in language processing. The Quarterly Journal of Experimental Psychology 69(5), 1013-1040. 
KIng Jeffrey, Stanley Jason (2005). Semantics, pragmatics and the role of semantic content. In Semantics vs. Pragmatics, Zoltán Gendler Szabó (ed.), 111-164. Oxford: Clarendon Press.

LAssiter Charles (2021). Particularized conversational implicatures and miraculous communication. Language Sciences 86(17), 1-9. https://doi.org/10.1016/j.langsci.2021.101401.

Levinson Stephen (2000). Presumptive Meanings: The Theory of Generalized Conversational Implicature Language, Speech, and Communication. Cambridge, MA: MIT Press.

Martí Luisa (2006). Unarticulated constituents revisited. Linguistics and Philosophy 29, 135-166.

Nerlich Brigitte, Clarke David (2001). Ambiguities we live by: Towards a pragmatics of polysemy. Journal of Pragmatics 33, 1-20.

PaApe Dario, Vasishth Shravan, Malsburg Titus von der (2020). Quadruplex negatio invertit? The on-line processing of depth charge sentences. Journal of Semantics 37(4), 509-555.

Petrus Klaus (2010). Paul Grice, philosopher of language, but more than that. In Meaning and Analysis: New Essays on Grice, Klaus Petrus (ed.), 1-30. Basingstoke: Palgrave Macmillan.

Qian Zhiying, Garnsey Susan, Christianson Kiel (2018). A comparison of online and offline measures of good-enough processing in garden-path sentences. Language, Cognition and Neuroscience 33(2), 227-254.

ReCanati François (1989). The pragmatics of what is said. Mind and Language 4, 295-329.

Recanati François (2002a). Does linguistic communication rest on inference? Mind \& Language 17, 105-126.

Recanati François (2002b). Unarticulated constituents. Linguistics and Philosophy 25, 299-345.

Recanati François (2004). Literal Meaning. Cambridge: Cambridge University Press.

Recanati François (2007). Reply to Carston. In Saying, Meaning, Referring: Essays on the Philosophy of François Récanati, Maria Jose Frapolli (ed.), 49-54. Basingstoke: Palgrave Macmillan.

Recanati François (2010). Truth-Conditional Pragmatics. Oxford: Clarendon Press. SAUL Jennifer (2002). Speaker meaning, what is said and what is implicated. Nous 36(2), 228-248.

SBISA Marina (2021). Presupposition and implicature: Varieties of implicit meaning in explicitation practices. Journal of Pragmatics 182, 176-188.

SEARLE John (1983). Intentionality. Cambridge: Cambridge University Press.

SEuren Pieter (2009). Language in Cognition: Language from Within. Oxford: Oxford University Press.

SoAmes Scott (2010). Philosophy of Language. Princeton: Princeton University Press.

Sperber Dan, Wilson Deirdre (1986/95). Relevance: Communication and Cognition. Oxford: Blackwell.

Sperber Dan, Wilson Deirdre (2002). Pragmatics, modularity and mind-reading. Mind \& Language 17, 3-23.

Sperber Dan, Wilson Deirdre (2005). Pragmatics. UCL Working Papers in Linguistics 17, 353-388. Reprinted in Oxford Handbook of Contemporary Philosophy, Frank JACKson, Michael Smith (eds.), 468-501. Oxford: Oxford University Press. 
Sperber Dan, Wilson Deirdre (2008). A deflationary account of metaphors. In The Cambridge Handbook of Metaphor and Thought, Raymond GibBs (ed.), 84-105. Cambridge: Cambridge University Press.

Stanley Jason (2000). Context and logical form. Linguistics and Philosophy 23, 391-434. StanLey Jason (2005). Semantics in context. In Contextualism in Philosophy: Knowledge, Meaning and Truth, Gerhad Preyer, Georg Peter (eds.), 221-253. Oxford: Clarendon Press.

Stanley Jason, Szabó Zoltán Gendler (2000). On quantifier domain restriction. Mind \& Language 15(2-3), 219-261.

Strawson Peter (1950). On referring. Mind 59, 320-344.

TAYLOR Kenneth (2001). Sex, breakfast, and descriptus interruptus. Synthese 128, 45-61. Terkourafi Marina (2009). What use is 'what is said'? In Utterance Interpretation and Cognitive Models, Philippe De Brabanter, Mikhail Kissine (eds.), 27-58. Bingley: Emerald.

Vicente Augustín, Martínez-Manrique Fernando (2005). Semantic underdetermination and the cognitive uses of language. Mind \& Language 20(5), 537-558.

WeTtstein Howard (1979). Indexical reference and propositional content. Philosophical Studies 36, 91-100.

Wharton Tim (2002). Paul Grice, saying and meaning. UCL Working Papers in Linguistics 14, 207-248.

Wharton Tim (2009). Pragmatics and Non-Verbal Communication. Cambridge: Cambridge University Press.

Wilson Deirdre, Sperber Dan (2002). Truthfulness and relevance. Mind 111, 583-632.

Wilson Deirdre, Sperber Dan (2004). Relevance theory. In The Handbook of Pragmatics, Laurence HORN, Gregory WARD (eds.), 607-632. Oxford: Blackwell.

Wilson Deirdre, Sperber Dan (2012). Meaning and Relevance. Cambridge: Cambridge University Press.

Zufferey Sandrine, Moeschler Jacques, Reboul Anne (2019). Implicatures. Cambridge: Cambridge University Press.

ŽEGARAC Vladimir (2006). Believing in: A pragmatic account. Lingua 116, 1703-1721.

Maria Jodłowiec

Instytut Filologii Angielskiej

Uniwersytet Jagielloński

Al. Mickiewicza 9A

31-120 Kraków

[maria.jodlowiec(at)uj.edu.pl] 